\title{
A Rússia na ordem mundial: com o Ocidente, com o Oriente ou um pólo autônomo em um mundo multipolar?
}

\section{ALEXANDER ZHEBIT*}

\section{Introdução}

Passados um pouco mais de dez anos desde a saída da Federação Russa de uma transformação radical, corolário da queda do Muro de Berlim, da dissolução da União Soviética e do fim da Guerra Fria, o interesse da comunidade internacional na sua transição e na sua evolução não se esvaeceu. Continua bem vivo e mantémse aquecido pelo fato de que ainda há mais perguntas do que respostas a respeito do objetivo, do caminho e do modelo da evolução da Rússia no futuro. Uma falta de clareza, quanto ao lugar que a Rússia ocupa e pretende ocupar no mundo contemporâneo, leva a tecer algumas considerações a respeito.

Depois do dramático período da desintegração e em meio a um complexo e traumático processo de transição - do estado unitário e da economia centralizada para uma sociedade democrática de direito e economia de mercado - aparecem sinais de uma estabilidade longamente esperada. Apesar de o PIB da Rússia ser equivalente a uma décima parte do PIB dos Estados Unidos ou da União Européia, ou a um terço do PIB da China ou a uma metade da economia brasileira, de sua população ter diminuído devido ao crescimento da taxa de mortalidade e em virtude das migrações populacionais desde a extinção da União Soviética, de 151 mil em 1990 a 147 mil em 2001, de o país ter sofrido uma dura crise financeira em 1998, a Rússia vem apresentando nos últimos quatro anos uma notável recuperação: 5,4\% de crescimento do PIB em 1999, 8\% em 2000, 5\% em 2001 e 4,5\% em 2002. O país pulou do quinto para o segundo lugar no mundo entre exportadores de petróleo e derivados e prepara-se para entrar na OMC. A Rússia paga adiantado juros e a parte de sua dívida externa para o Clube de Paris e o FMI, antecipando os prazos estabelecidos, com expectativa de terminar os pagamentos da dívida em oito a dez anos. O Presidente Putin mantém a aprovação de 70\% a 75\% dos 
entrevistados nas sondagens da opinião pública russa a respeito da situação na Chechênia. O panorama político do país caracteriza-se pela relativa calma se comparado com a crise de 1993 ou a luta pré-eleitoral de 1996.

Nesse panorama de relativa estabilidade política e de avaliação otimista da recuperação da economia russa, desenvolve-se uma expectativa de que a política russa encontrou uma fórmula para sua evolução a curto e a médio prazo, está saindo de sua pior fase, vem ganhando maior credibilidade de investidores e de homens de negócios, mas, apesar de todo potencial positivo, ainda não conseguiu traçar sua perspectiva política de longo prazo. Tanto essas considerações como as observações referentes às modificações de conceitos da política externa ou de segurança comprovam certo desempenho imediatista e demonstram uma incerteza relativa do rumo em termos de inserção política global e em termos de crescimento econômico e desenvolvimento. É desnecessário dizer que, depois do fim da bipolaridade, muitos países, tanto ocidentais como asiáticos, depararam-se diante do problema de re-ordenamento de suas estratégias e políticas. No entanto, eles mantiveram, na sua maioria absoluta, o entrosamento característico para a fase posterior ao desmoronamento do bloco soviético no âmbito da UE, Otan, OCDE, UEO, Asean, OEA, OUA e outros organismos, procurando revigorar a sua atuação nessa rede de alianças e relações. A Rússia, ao perder uma rede substancial de alianças (Pacto de Varsóvia, Conselho de Ajuda Mútua Econômica, tratados bilaterais de amizade e cooperação com os antigos aliados, estruturas de relações interpartidárias e intersindicais) e ao retrair-se geograficamente, expôs-se a uma reestruturação radical de seus vetores políticos externos, cuja grande parte ficou sem norte, indeterminada ou sem sentido. Não são fortuitas, portanto, as recorrências aos precedentes e padrões da política da Rússia imperial anteriores ao período soviético e a busca do norte por meio do repensar dos esquemas políticos e estratégicos, dos procedimentos diplomáticos da época, inclusive por meio do estudo de estilos dos grandes estadistas e chanceleres da Rússia pré-soviética. ${ }^{1}$ Constatada essa perda do norte que caracteriza a política da Rússia em geral, é oportuno observar que, depois dos longos anos de predominância na sociedade do paradigma do messianismo universalista, o eixo do debate político nesses últimos anos vem sendo modificado graças ao binômio ocidentalismo/orientalismo, importante tema de discussões referentes à orientação da política externa russa no âmbito da comunidade acadêmica e entre partidos políticos na Duma².

Com vistas ao acima referido, a nossa intenção é, com base na construção de várias premissas de ordem teórica, sem pretensão alguma de originalidade de opinião, tentar traçar conseqüências para a conjuntura internacional resultante de algumas opções que a Rússia pretende fazer ou já vem fazendo na sua política externa.

Logo abaixo são relacionadas premissas básicas de alguns cenários da futura inserção da Rússia na ordem mundial, ao mesmo tempo contínua e mutante, 
que, em tese, poderão ser discutidas com respeito à Rússia pós-yeltsiniana. Será que ela se voltará ao Oriente para construir seu futuro com seus grandes vizinhos asiáticos como a China, a Índia, quiçá, o Japão? Será que a ocidentalização do país resultará na incorporação da Rússia pelo Ocidente e na sua identificação com os valores humanos, políticos, civilizacionais ocidentais? Será que a Rússia tentará se consolidar como um pólo original e independente de poder, em um mundo multipolar, sem preferências estratégicas e civilizacionais? Ou, então, a Rússia desistirá dos velhos estereótipos baseados em analogias históricas e ideologias saudosistas e escolherá uma opção original de sua inserção internacional? Essas colocações básicas de cenários da futura inserção da Rússia na ordem mundial são assuntos de comentários neste artigo com a seguinte salvaguarda. Segundo alguns propósitos analíticos, a Rússia, guiada por seus políticos, seria reticente e inconformada em se dirigir aos espaços ocupados por outras civilizações. Portanto, por um lado, não irá aonde não é desejada ou receada como aliado ou parceiro com intenções imperialistas e, por outro, não será aceita pelos sistemas de alianças rígidas que não prevêem uma participação russa. ${ }^{3}$ Porém, essa opção estritamente isolacionista (em termos práticos, reminiscente do recente passado soviético) está rejeitada como uma evolução absolutamente indesejável quase consensualmente pela sociedade e por partidos políticos por apresentar um beco sem saída e por condenar qualquer um dos modelos de desenvolvimento da Rússia no século XXI avaliados neste artigo.

\section{Vetor asiático e oriental da política externa da Rússia}

Ocorrida a mudança nos escalões de poder interno da Rússia depois da eleição, em março de 2000, de Vladimir Putin como Presidente da Federação Russa, a percepção que se obtém a partir da análise de vários sinais dados pela diplomacia russa na Europa, nas relações com os Estados Unidos e nos avanços conseguidos com os vizinhos europeus, asiáticos e do Oriente Extremo é que, em primeiro lugar, a política externa russa está mais equilibrada, sobretudo pela atenção redobrada que a Rússia de Putin tem dado à Ásia e ao Oriente, e que, em segundo lugar, houve uma modificação visível no rumo da política externa em comparação com a fase anterior (sobretudo o período do ex-chanceler Vladimir Kozyrev), que se caracteriza agora pela reaproximação com a Coréia do Norte, Vietnã, Cuba, Irã e Iraque. Essa mudança de postura tornou-se mais perceptível desde a nomeação de Evgueni Primakov para o posto de Ministro dos Negócios Estrangeiros da Rússia e, sobremaneira, desde o desentendimento havido entre a Rússia e os países-membros da Otan quanto às interpretações divergentes da intervenção humanitária da organização em Kosovo. A “ofensa” de Kosovo, demonstrada como uma démarche para o cancelamento da visita oficial aos Estados Unidos e para o retorno surpreendente do primeiro-ministro Evgueni Primakov à Rússia, já 
em pleno vôo sobre o Atlântico, era um precedente precursor dessa mudança de atitude.

O choque sentido pelos dirigentes russos nesse caso foi de dupla natureza: primeiro, pelo desprestígio causado pela ingerência do Ocidente na área considerada uma zona de interesse estratégico, devido ao alto grau de confiança mútua nas relações russas com o regime de Milosevic; segundo, pela desconsideração da política russa na região, cujos precedentes históricos recuam ao final do século XIX e estão relacionados com episódios da presença militar (na Romênia e na Bulgária) e econômica (na Iugoslávia) nos Bálcãs, povoados pelos povos eslavos. O ressentimento, portanto, era uma das principais razões para que os russos acrescentassem uma boa pitada de rapé nas relações com os países da Otan e os Estados Unidos, a partir de 1999, e começassem a explorar opções orientais.

Uma alienação da Rússia em relação ao Ocidente, que tem fundamentos históricos, inclusive baseados no período recente da Guerra Fria e que continua sendo tachada pelas atuais tensões nas relações russo-americanas e Rússia-Otan, esteve na origem da proposta de uma nova política asiática da Rússia, definida em termos do famoso triângulo estratégico de Primakov "Moscou-Délhi-Pequim". A iniciativa diplomática do ex-Primeiro-ministro russo, um orientalista pela formação e pela vivência profissional, anunciada durante sua visita oficial à Índia, veio esbarrar contra uma série de fortes objeções e uma frieza de aceitação tanto dentro quanto fora do país, abalando fundamentos propostos para uma alternativa sólida na política externa russa. Em primeiro lugar, os interesses estratégicos e políticos da Rússia, da China e da Índia, de um modo geral, coincidindo em assuntos globais, não convergem em assuntos regionais ou divergem em assuntos concretos. Segundo, seus valores básicos civilizacionais, éticos e culturais são distintos. Terceiro, seus interesses econômicos nas áreas não-conflitantes não são totalmente coincidentes. A China, "economia de mercado socialista", define os seus interesses nacionais em termos da solução do problema de Taiwan e da promoção comercial. A Índia, “a maior democracia mundial”, fora da preocupação com as forças centrífugas dentro de sua federação, investe na solução do conflito indo-paquistanês por vias não necessariamente pacíficas. A Rússia, economia ex-socialista em transição ao mercado e ao estado de direito, envolvida na eliminação do foco da "dissidência" chechena, está mais preocupada com o controle administrativo de sua imensidão territorial e com a instabilidade no seu "anel de vizinhança” caucasiano e asiático. Cada um dos países, em fases diferenciadas de desenvolvimento econômico, poderia cooperar em assuntos comerciais, econômicos, ecológicos, tecnológicos e de investimentos, mas está longe de criar um sistema de parceria estratégica à la Otan como podia ter sido visto por Evgueni Primakov. Os termos estratégicomilitares de tal parceria não poderiam ser viabilizados nem dentro da ótica de valores comuns, nem dentro de determinados interesses políticos, nem da cooperação nas referidas áreas. O Tratado de boa vizinhança, amizade e cooperação 
com a China assinado em julho de 2001, um documento de parceria estratégica e cooperação econômica, não reflete objetivos político-militares, não é um manifesto antiamericano e não visa criar uma coalizão político-militar que se oponha a quem quer que seja, diferentemente do Tratado de ajuda mútua firmado entre Stalin e Mao-Tsetung há meio século. A venda maciça de material bélico russo à Índia não implica nenhuma parceria estratégico-militar com a Rússia e está se realizando em função da necessidade de uma maior autonomia militar indiana no conflito com o Paquistão e no equilíbrio estratégico com a China. O relacionamento da Rússia com o Japão continua embargado pela disputa territorial sobre o arquipélago de Pequenas Curilas.

Mesmo com as fortes justificativas de que a opção oriental da Rússia não se constituiu e provavelmente não se constituirá num vetor estratégico de longo prazo, nada nos impede de concluir que a mudança nos escalões de poder interno da Rússia, depois da eleição de Vladimir Putin, fez com que a parceria com o Ocidente, iniciada, mantida e, de certo modo, privilegiada por Yeltsin, ficasse equilibrada pelo ressurgimento de atividades bilaterais que a Rússia de Putin tem efetuado em relação a vários países asiáticos, como a Índia, a China, o Japão, a Coréia do Sul, o Vietnã, sem esquecer os que os Estados Unidos de George W. Bush classificaram de o "eixo do mal”: a Coréia do Norte, o Iraque e o Irã. Devese fazer uma ressalva importante: essa modificação de rumo, em comparação com o período yeltsiniano, sobretudo, com respeito aos quatro últimos, não se transformou, no entanto, numa política de longo prazo, por não ter uma base conceptual definida e por ter provocado críticas por ser antiocidental ${ }^{5}$. O orientalismo, portanto, não se transformou numa opção estratégica de longo prazo a custo de qualquer outro vetor político externo.

\section{Vetor ocidental da política externa da Rússia}

A opção ocidental na política externa russa é um vetor novo, que surge a partir da superação da fase confrontacional da Rússia com o Ocidente de cerca de meio século de duração. Numa flexão de sua trajetória, a opção pelas alianças e parcerias ocidentais contribuiu para o reforço e a garantia de segurança das posições internacionais da Rússia na etapa de sua inserção pós-soviética e pósbipolar nas estruturas estratégicas, econômicas e financeiras do Ocidente.

Pegando o lado econômico, não há dúvida de que a política ocidental da Rússia obteve vantagens a partir da associação com organismos financeiros e econômicos governados pelo Ocidente. Só que essas vantagens foram recebidas com bastante frustração pela população que não sentiu os devidos efeitos da reforma econômica no plano interno (cresceu a dívida externa, deflagrou-se uma crise financeira em agosto de 1998, o PIB e a renda per capita ficaram diminutas e investimentos escassos). Em termos do relacionamento externo com a Europa 
Ocidental e os Estados Unidos, a expansão da Otan para o Leste, a intervenção da Otan na Iugoslávia sem que houvesse a autorização do Conselho de Segurança e a promoção dos interesses geoestratégicos do Ocidente no Cáucaso e na Ucrânia foram recebidos com profunda amargura, associada à percepção de que os "parceiros” ocidentais partiam do pressuposto de que a Rússia não tem alternativa à aceitação dos interesses ocidentais, que sua debilidade estatal, fraqueza econômica, dependência financeira do Ocidente atrapalham a atuação independente na cena internacional.

Portanto, além de ser um vetor recente, a orientação pelo Ocidente é avaliada por nacionalistas e comunistas russos como uma direção inviável; já pela opinião pública em geral como uma opção questionável e não uni-direcional, criandose, assim, uma polêmica em torno da acepção generalizada da ocidentalização da Rússia e com respeito à busca da "via russa"6.

O que acrescenta lenha ao debate sobre a ocidentalização é que o conceito de coesão transatlântica do Ocidente está fragilizado pelo debate que tem ocorrido há alguns meses nos círculos acadêmicos dos Estados Unidos e da Europa. O surgimento de uma séria cisão dentro do Ocidente, entre os Estados Unidos e a Europa, cuja harmonia unificadora se encontra atingida por um desacordo fundamental, foi apontado no comentado artigo de Robert Kagan, publicado na revista Policy Review em julho do ano passado ${ }^{7}$.

Esse argumento encontra eco nas idéias expostas por Hélio Jaguaribe a respeito do Ocidente e elaboradas dentro do paradigma histórico-social quando ele escreve: "Abre-se [...] um novo conflito entre o sentido de eficácia e os valores do humanismo[...]. Desse dilema se confrontam, na cultura ocidental, por um lado, Estados Unidos e um Japão ocidentalizado e, por outro, a Europa e a América Latina"8.

Ao aceitar os argumentos expostos acima, podemos deduzir que dentro desse raciocínio surge um importante dilema para a política russa atual: qual dos Ocidentes seria mais favorável aos interesses vitais da Rússia? Onde a Rússia preferiria lançar a sua âncora? No Ocidente hobbesiano, dominado pelas preferências políticas hegemônicas, ou no Ocidente grociano, cuja indefinição em termos do relacionamento com a Rússia lança dúvidas e provoca questionamentos? No Ocidente dos Estados Unidos e da hegemonia “uni-multipolar” ou no Ocidente da Europa unida, que traçou e envereda pela via da construção de uma prosperidade compartilhada e solidária em condições da paz kantiana?

Talvez, a colocação do dilema, seja muito importante pelo motivo seguinte: é que a própria posição da Rússia mudou significativamente durante a última década. Se esse questionamento tivesse surgido há uns quinze anos a pergunta seria: para qual dos lados a Rússia (então União Soviética) daria sua preferência e acrescentaria seu peso? A questão que colocamos agora é: com qual dos lados a Rússia se aliaria para não perder seu peso? 
Desse ponto de vista, as relações com os Estados Unidos ou com a União Européia devem ser vistas através do prisma de parceria estratégica com o Ocidente, que significaria a identificação dos interesses nacionais russos com os interesses e valores comuns da comunidade estratégica ocidental, principalmente a Otan, e que, apesar das divergências circunstanciais, continuam sendo compartilhados. Tal fato implicaria o reconhecimento da Rússia como parceiro importante e levaria sua inserção nos organismos econômicos multilaterais, principalmente a OMC, com o beneplácito do bloco ocidental ${ }^{9}$.

Porém, se aplicarmos a essa hipótese o teste das relações bilaterais russoamericanas, ela será encarada na Rússia com bastante ceticismo, visto que, literalmente, até há pouco tempo não havia identificação de interesses comuns de longo prazo entre os Estados Unidos e a Rússia. Até os ataques terroristas de 11 de setembro, talvez o único problema que cada um dos países considerava comum dentro do paradigma de segurança nacional e se comprometia com sua solução concertada era o fator nuclear dentro do propósito do desarmamento nuclear paritário.

As relações da Rússia com os Estados Unidos nos anos 90 tiveram uma fase de profundas transformações positivas, mas entraram numa trajetória descendente no final do governo Clinton. A expansão da Otan e a insistência com que os Estados Unidos pressionavam a Rússia a abandonar e nulificar o ABM Treaty (Antiballistic Missiles Treaty) de 1972, avançando o plano da instalação do MDS (Missiles Defense System), colocaram o governo de George W. Bush perante uma opção: continuar a parceria estratégica nuclear com a Rússia baseada na paridade, mantendo lealdade ao Tratado, em princípio obsoleto e contornável, ou sair do Tratado, quebrando o esquema paritário, deixando a Rússia receosa de uma iniciativa defensiva, que, por ter similitude com a SDI (Strategic Defense Initiative de Ronald Reagan), provavelmente empurraria a Rússia para a corrida armamentista dentro do velho esquema bipolar. Quando a renúncia unilateral aconteceu no final de 2001, a reação de Vladimir Putin foi mais do que reservada. Por quê? O novo líder russo entendeu, em primeiro lugar, que qualquer concorrência na área estratégico-nuclear com os Estados Unidos resultaria em sacrifícios catastróficos para a economia do país, a exemplo das conseqüências da competição entre as superpotências para a União Soviética, e, em segundo, que a configuração e o teor das ameaças para a segurança da Rússia mudou de tal maneira que não somente os Estados Unidos desapareceram da relação dos seus inimigos, como também a própria lista de inimigos deixou de existir ${ }^{10}$.

Essa controvérsia de caráter estratégico que resultou numa complexificação dos problemas bilaterais, dadas as posturas desfavoráveis ou reservadas tanto dos oponentes como dos aliados, não é a única área das divergências que carateriza as relações entre a Rússia e os países ocidentais. Nas seguintes áreas de importância 
geoestratégica e geoeconômica, vários interesses do Ocidente e da Rússia não convergiam, eram ou poderiam ser conflitantes no futuro.

\section{a) A expansão da Otan}

A expansão da Otan em direção às fronteiras da Rússia provocou uma séria preocupação dos militares e políticos russos de diversas orientações partidárias. As mudanças na doutrina militar da Rússia em 2000 foram o resultado direto da estratégia expansionista da Otan (adesão da Polônia, República Tcheca e Hungria), exacerbada pela desconsideração com que a Rússia foi tratada no conflito de Kosovo. Essas modificações doutrinárias, em comparação com a versão de 1997 da mesma doutrina, permitiram uma complementação de situações nas quais a Rússia pudesse recorrer ao uso de armas nucleares, como por exemplo, em caso de uma agressão de envergadura com o uso de armas convencionais contra a Rússia e que colocaria sua sobrevivência como Estado em cheque. ${ }^{11} \mathrm{~A}$ Parceria pela Paz que incluiu a Rússia em consultas com a Otan a partir de 1997 não afastou o pensamento de que os supostos desígnios políticos e estratégicos dos Estados Unidos e dos aliados da Otan na Europa visam o domínio e a substituição da Rússia na região do antigo bloco soviético na Europa de Leste e no Cáucaso.

\section{b) Os países bálticos}

A extensão da Otan aos países Bálticos - Letônia, Lituânia, Estônia, cuja reintegração na União Soviética em 1940 nunca tinha sido reconhecida pelos governos ocidentais por ser qualificada como uma anexação - foi tratada pelos militares e pelos políticos nacionalistas russos como um passo ao caminho da acumulação de ameaças à segurança da própria Rússia, cujos centros industriais e instalações militares, principalmente a cidade de São Petersburgo, estariam vulneráveis caso uma situação de instabilidade nos Balcãs ou no Cáucaso provocasse mudanças na concentração de forças armadas e de armamentos convencionais nos flancos do continente europeu, uma vez que os referidos países bálticos não são parte do Tratado de Limitação das Forças Armadas Convencionais na Europa ${ }^{12}$. O enclave russo de Kaliningrad (antiga Köenigsberg da Prússia Oriental), separado do mainland russo pela Lituânia e Letônia, enfrenta uma situação de isolamento humanitário e econômico, uma vez estar ligado à adesão, a partir do ano de 2004, dos três estados bálticos e da Polônia, República Tcheka, Hungria, Eslováquia à União Européia. Enquanto isso, os planos e ações de implantação da infra-estrutura de radares da Otan na Letônia, em substituição das estações russas, causam comentários cáusticos dos nacionalistas russos sobre a falta de firmeza do governo russo face à expansão da Organização do Tratado do Atlântico do Norte para o Leste. 


\section{c) A Comunidade dos Estados Independentes}

Além de concentrar na periferia vários conflitos entre e dentro das antigas repúblicas da União Soviética, a região é uma arena de concorrência entre os Estados Unidos e a Rússia pelo acesso aos recursos energéticos (petróleo e gás) e pelas vias de seu transporte. Enquanto a Rússia insiste, pelas razões óbvias, em rotas que passariam pelo território russo, os Estados Unidos se manifestam pelas vias múltiplas e alternativas, sob pretexto das hostilidades na Chechênia, para conseguir submeter novos produtores de petróleo na região, como o Turcomenistão, ao controle estratégico ocidental. O dinamismo da política externa dos Estados Unidos no Cáspio e no Cáucaso (o jogo de interesses petrolíferos na região e o envio de conselheiros militares na Geórgia) e recentemente a entrada do pessoal militar nos países da Ásia Central, em conseqüência da utilização das bases daqueles países no combate às forças armadas dos talibãs e aos campos de treinamento da Al-Qaeda no Afeganistão, podem inquietar os dirigentes russos. A penetração política, econômica e militar da atual superpotência na zona de interesses declarados da antiga superpotência causa preocupação e provoca tomadas de posições. Enquanto os Estados Unidos vêem a Ucrânia como uma pretendente à candidatura para a Otan e avaliam tudo que possa incentivar a reintegração do espaço póssoviético, como por exemplo a unificação de Belarus e da Rússia como uma forma saudosista de imperialismo russo, a Rússia cria redes e bases de suas relações futuras com o seu “exterior próximo”: em 1997-1998 funda-se uma união Rússia - Belarus (a república de Belarus visualizada por estrategistas como um cunho, embutido na área de segurança da Otan); as relações econômicas com a Ucrânia vêm sendo solidificadas com o objetivo de mantê-la neutra e afastada da Otan; instala-se pela iniciativa da Rússia em 2000 um bloco econômico chamado de Comunidade Econômica da Eurásia ${ }^{13}$; e, enfim, tolera-se a presença militar americana no Uzbequistão para receber a contrapartida em termos de apoio dos Estados Unidos à operação militar na Chechênia. Cum grano salis, pode se acrescentar que um sólido segmento dos russos considera a campanha da defesa dos direitos humanos na Chechênia, conduzida pelo governo americano, como uma manobra dirigida para enfraquecer a defesa da unidade federal da Rússia e suas posições no "exterior próximo".

\section{d) Os Bálcãs}

Por um lado, a intervenção da Otan nos Bálcãs, particularmente na antiga Iugoslávia, foi interpretada pelos dirigentes russos como uma ingerência na esfera de influência política russa, e, por outro, como um atentado à tradição histórica eslava e ortodoxa realizada por meio do castigo infligido ao regime de Milosevic e, indiretamente, por intermédio do apoio aos muçulmanos de Kosovo. Sobretudo, a 
intervenção humanitária em Kosovo aconteceu em contravenção da Ata de Fundação de Cooperação entre a Rússia e a Otan assinada em Paris em 1997, segundo a qual os dois lados se comprometiam a evitar usar a força contra qualquer Estado de maneira inconsistente com a Carta das Nações Unidas. Isso não foi evitado. O que agravou a situação é que os Estados Unidos desaprovaram ao mesmo tempo a pressão militar e humanitária da Rússia sobre a Chechênia, tal atitude sendo considerada na Rússia como sem critério.

\section{e) O Oriente Médio}

É uma região caracterizada no passado pela confrontação entre as duas superpotências. A situação mudou e as vias de solução do conflito israelensepalestino passam pela cooperação multilateral (a tetrarquia dos Estados Unidos, da Rússia, da ONU e da União Européia) e não por meio de consultas bilaterais de então. Uma crítica às posturas de força dos Estados Unidos em relação ao Iraque tem um caráter declaradamente expresso. Um novo divisor separa dos Estados Unidos as posições da Rússia e de outros integrantes permanentes do Conselho de Segurança. As divergências se referem à manutenção das sanções contra o Iraque, à cooperação da Rússia na área tecnológica e nuclear com o Irã e, finalmente, à respeito da Resolução do Conselho de Segurança 1441 referente ao desarmamento biológico e nuclear do Iraque. O último plano de paz para o Iraque, apresentado por Alemanha e França, que visa a presença dos "capacetes azuis” no Iraque para apoiar as atividades dos inspetores da ONU, mostra quão grande é a insatisfação dos europeus, entre eles dos russos, com os planos emergenciais de guerra contra o Iraque elaborados pelos Estados Unidos

\section{f) O Extremo Oriente}

Nessa região os interesses estratégicos da China, da Rússia e dos Estados Unidos não convergem, criando a situação em que a parceria estratégica antichinesa entre o Japão e os Estados Unidos em relação ao problema de Taiwan e o litígio russo-japonês, referente ao arquipélago de Pequenas Curilas, não estão equilibrados pelos entendimentos político-estratégicos russo-chineses, o que derruba perspectivas de uma diplomacia triangular ${ }^{14}$. A reunificação das duas Coréias, processo endossado pelo Ocidente, pela Rússia e pelo Oriente, poderá deixar de evoluir em função do aprofundamento das diferenças nas posições dos Estados Unidos e do Japão, por um lado, e da Rússia e da China, por outro, sobretudo quando o problema de proliferação nuclear na Coréia do Norte começa a se agudizar, chegando a proporções de uma identificação ideológica (“o eixo do mal”).

Uma breve análise das divergências que separam as posições internacionais da Rússia das dos Estados Unidos poderia nos levar a conclusões diametralmente 
opostas. Se a Rússia se ativesse a uma posição maximalista, o vetor ocidental de sua política externa poderia estar condenado ao fracasso, por tantas áreas de divergência e de conflito existirem nas relações com o líder do Ocidente. Se mantivesse uma posição minimalista, ela se aliaria ora a um, ora a outro pólo ocidental em função do interesse nacional, motivada a salvaguardar suas posições num jogo de contradições entre os grandes, por estar em estado de transição e de incertezas com respeito à finalidade de seu destino nacional.

Acho que tirando essa ou aquela conclusão, estaríamos errados. A realidade e a razão entram em conflito quando se trata da Rússia, tanto hoje como há décadas ou séculos. Como dizia Bismarck, a Rússia nunca é tão forte ou tão fraca quanto parece. A precisão desta observação está certa como nunca. A Rússia não tem força bastante para renunciar ao vetor ocidental na sua política, e mesmo se tivesse, não o faria, pois seria um suicídio político internacional. Mas ao mesmo tempo a Rússia não é tão fraca para ser um objeto dócil e passivo da política ocidental. Portanto, ela deixa para si uma opção.

Se passarmos novamente em revista das áreas analisadas acima, substituindo os Estados Unidos pela União Européia, surgirá um quadro diferente. O alargamento da União Européia para o Leste é elogiado ou tolerado pela Rússia, em contraste à expansão da Otan. A possibilidade de admissão dos países bálticos na União Européia aproxima a Rússia, suas potencialidades econômicas e comerciais às suas fronteiras, abrindo perspectivas de criação do espaço econômico integrado com a UE. A CEI, que está em formação dentro do espaço pós-soviético, seria em grande medida beneficiada pela extensão oriental da UE desde que sejam observadas condições de equidade e de parceria. No Oriente Médio, a Rússia e a UE são parceiros do processo de solução pacífica do conflito e no Extremo Oriente seus interesses não são contraditórios. O baixo perfil da política comum de segurança e defesa (Pesc) da UE, sobretudo em relação aos conflitos tanto intraeuropeus quanto extra-europeus, e a proximidade das mentalidades formadas durante séculos de convívio entre os russos e os europeus representam fortes atrativos para preferenciar o vetor europeu e não meramente ocidental de sua política externa, diminuindo a percepção de ameaças que emanam principalmente dos Estados Unidos da América e não da Europa.

As relações da Rússia com a União Européia estão longe de serem conflitantes. Mas a falta de contradições no momento atual não significa que essas não apareceriam no futuro quando a Europa dos 28 se transformar num superestado (con)federal, com a economia mais forte do mundo, a Rússia podendo criar uma dependência econômica de alto grau em relação à União Européia, poderia ser questionada internamente.

A identidade européia favorece a adesão da Rússia à União Européia, mas antes de fazer esse passo, a Rússia terá que remediar e consolidar relações com os Estados Unidos. Isso significa que - nas condições de um desnível enorme 
dos potenciais russo e americano - a Rússia precisaria rever o sistema dos seus interesses de política externa e de segurança a favor da priorização dos interesses americanos com respeito aos da Rússia. Isso significaria um distanciamento da linha política independente da Rússia na Eurásia, característica do período da bipolaridade e do pós-Guerra Fria. Ao adotar uma linha soberana na Eurásia, a Rússia não poderá contar com uma integração completa na Grande Europa. O resultado seria a expansão da Otan e da União Européia com base no transatlantismo, sem eurasismo. A opção européia da Rússia seria um projeto, que não sairá do papel se não forem considerados os relacionamentos russoamericano e russo-chinês. Para isso é necessário aproveitar ao máximo a concorrência entre a União Européia e os Estados Unidos, levando em consideração que a integração na área de segurança atrai a União Européia aos Estados Unidos e a integração econômica os distancia. Portanto, o imperativo político da Rússia seria transferir a cooperação com a Europa do plano estratégico-militar para o plano econômico.

Portanto, a opção que se sugere é a seguinte: dentro da diretriz ocidental da política externa russa, a ramificação que a Rússia preferiria é européia.

\section{Pólo autônomo de poder num mundo multipolar?}

As divergências no âmbito das relações bilaterais e multilaterais com o Ocidente, sobretudo com os Estados Unidos acima assinaladas, bem como a falta de receptividade das iniciativas estratégicas da Rússia pela parte da China e da Índia no sentido da formação de uma coalizão do Oriente que pudesse contrabalançar a hegemonia unilateral da única superpotência, levam-nos à opinião de que a Rússia pode ser imaginada como um ator geo-estratégico de grande peso numa área de extensão gigantesca, o heartland do planeta, onde estão presentes simultaneamente os interesses dos maiores atores mundiais - os Estados Unidos, Alemanha, Grã-Bretanha, França, China, Índia e Japão. A posição da Rússia na confluência dos caminhos da cooperação entre a Europa e a Ásia estimula os grandes atores da ordem mundial a tentar envolver a Rússia em esquemas ou de cooperação ou de rivalidade estratégica, política, econômica e comercial, que passam por seu envolvimento em três principais estruturas transregionais e transnacionais: segurança internacional, economia e comércio globais, e redes globais.

O objetivo óbvio perseguido pelo Presidente russo consiste em fortificar e solidificar o Estado cujo poder determine uma economia estável, fortaleça a coesão da Federação Russa, assegure um controle eficaz sobre lavagem de dinheiro e corrupção, previna a oligarquização e a cartelização e iniba as atividades terroristas e de crime organizado ${ }^{15}$. Na linguagem política internacional, esse objetivo manifesta-se na intenção, apoiada pelos saudosistas da época da "superpotência”, 
de solidificar a posição da Rússia nas relações internacionais. O conceito da política externa da Rússia, recentemente adotado, diz claramente que “a Rússia estará trabalhando para construir um sistema multipolar das relações internacionais que reflita a realidade multifacetada do mundo contemporâneo com a diversidade de seus interesses"16, entendendo-se com isso que a Rússia deveria ser o tal "pólo". No entanto, entre a solidificação da posição da Rússia nas relações internacionais e a criação de um pólo de poder no mundo multipolar dentro do esquema traçado, com o fim de criar um contrabalanço à posição central dos Estados Unidos da América no sistema internacional, há um longo caminho a percorrer.

A idéia de Estado forte, sobretudo quando se trata da Rússia, é recebida com desconfiança pelos críticos do conceito da Rússia forte, que preferem que o complexo de inferioridade e de humilhação causado pelo processo da desintegração da União Soviética seja curado pela prosperidade consumista, induzida pelos capitais e investimentos ocidentais, enquanto a preocupação com a grandeza e o poder deva estar ofuscada ou reduzida ao mínimo para que se possa evitar o ressurgimento de ranços imperialistas na política russa. A Rússia deveria ter optado pelo caminho da Alemanha e do Japão no pós-guerra, ou da Turquia depois do colapso do Império Otomano, na opinião de Zbigniew Brzezinski ${ }^{17}$, para assegurar que sua transição ocorresse sem os sacrifícios desnecessários feitos no decorrer da reforma econômica e política na Rússia de Gorbachev e, posteriormente, durante a "breve década” de Yeltsin.

Com essas colocações, outro dilema é enfrentado na avaliação da política russa: almejar uma posição independente, baseada no reconhecimento de poder de primus inter pares, ou se contentar com a condição de submissão e de dependência, sem autonomia nas decisões. O argumento que se coloca é que, se a Rússia não se tornar um pólo num suposto mundo multipolar, então ela será reduzida à condição de vassalo político. Nessa contraposição, pode-se farejar uma tentativa de chantagem, uma exploração do sentimento de orgulho nacional, um convite provocativo a exercícios políticos como a competição entre os dois sistemas, a concorrência e a rivalidade entre as superpotências, e a corrida extenuante aos armamentos que custaram à Rússia enormes sacrifícios durante a Guerra Fria. Onde está a verdade e onde está a suposição?

Pela sua condição natural, a Rússia é uma grande potência, cujo status continua inquestionável apesar da redução drástica de seu PIB nos anos 90, o que deve ser reconhecido pelos proponentes da "turquização" da Rússia. É um país bicontinental gigantesco, cercado por seis regiões geo-estratégicos importantes Europa do Norte, Europa Central e do Leste, Bálcãs, Oriente Médio, Ásia Central, Sul da Ásia e Extremo Oriente -, uma importante parte delas apresentando tendências de instabilidade política ou de confrontos étnicos e religiosos. A situação explosiva em cada uma dessas regiões precisa ser contrabalançada pela forte e equilibrada política externa russa, baseada nos interesses de segurança e de 
estabilidade interna. O próprio “exterior próximo” apresenta uma zona de instabilidade e de conflito, que, apesar da desintegração exangue, evoluiu para um palco de lutas intestinas, nas quais a presença das forças armadas da Rússia (de manutenção de paz, de guarda-fronteiras ou de preservação de integridade federal), desempenha um papel salutar de estabilização ou de manutenção de um frágil equilíbrio. O separatismo checheno no interior da Rússia e o radicalismo islâmico no exterior são outros fatores que elevam o país ao ranking de aliados do Ocidente no combate ao terrorismo internacional que é fomentado pelo radicalismo islâmico e ao mesmo tempo desestimula o desarmamento e a pacificação à maneira alemã ou japonesa pós-guerra.

O reverso da moeda é o seguinte. A sobrevivência da Rússia como Estado forte e federado consiste numa compreensão clara de que o sucesso econômico da Rússia estaria em proporção inversa ao grau de confrontação externa e interna em que estaria envolvida. Para conseguir isso, a desistência do confronto e da rivalidade na cena internacional, a normalização da situação na Chechênia por meio da consolidação do federalismo ${ }^{18}$, tornam-se prioritárias para a recuperação econômica da Rússia. A desierarquização dos assuntos da pauta da política interna e externa, a preferência dada aos fatores econômicos, financeiros e comerciais, a gradual substituição dos debates internos sobre high politics pelos debates sobre low politics, são características para uma sociedade em transição que está ultrapassando as conseqüências de sua empolgação com a megalomania ideológica. No entanto, transformá-la num pólo dentro de um esquema de rivalidade à l'ancienne, em detrimento de sua recuperação econômica, da implantação do mercado, da construção de um Estado de direito e de uma democracia representativa, significaria sacrificar o objetivo mais imediato e mais urgente do país - o da inserção e da integração no sistema econômico mundial. A integração na economia mundial deve realizar-se pela Rússia com base na compreensão de que suas necessidades estratégicas precisam ser adaptadas aos seus interesses e capacidades econômicas.

Portanto, conciliar a vocação natural russa resultante da situação geográfica, da responsabilidade estratégica e da riqueza natural com a necessidade de recuperação e prosperidade econômica e de liderança na integração regional, sem despertar suspeitas de neocomunismo e neo-imperialismo e sem entrar em rivalidades induzidas e desnecessárias, tal seria a fórmula de consolidação da Rússia como grande potência regional. Pode ser reduzida à seguinte sentença: ser um pólo, sem precisar ser um.

Uma observação referente ao conceito de multipolarismo. Considerado benéfico pelos adeptos do paradigma estruturalista, visto que admite a autonomia de diversos centros de poder e diminui a dependência, o multipolarismo é avaliado pelos realistas como o fundamento do equilíbrio de poder e, respectivamente, pelos idealistas como a origem dos males relacionados com a instabilidade do sistema 
internacional, resultando em crises, conflitos e guerras. Claro que no mundo de hoje o multipolarismo não existiria desvinculado das organizações e regimes internacionais, portanto, seria, de uma maneira geral, controlado no âmbito da governança global, mas controlado inadequadamente e limitadamente. As brigas entre os pólos impediriam o funcionamento dos organismos e dos regimes, como, por exemplo, a divergência entre os membros permanentes do Conselho de Segurança (os Estados Unidos e o Reino Unido vs. a França, junto com a Rússia e a China), quanto à eventualidade da guerra contra o Iraque, desestabilizou as Nações Unidas e a Otan.

Uma consideração de sérias repercussões a esse respeito é que, devido ao desaparecimento da bipolaridade, muitos atores estatais ficariam incentivados a adquirir armas de destruição em massa, seguindo o paradigma do dilema de segurança. Se antigamente o bipolarismo, com seus instrumentos de coerção, dissuasão e de controle dos aliados conseguia bloquear as tendências de proliferação nuclear, a atual “debilitação do papel das Nações Unidas” quanto ao controle do uso de força cria incentivos para a nuclearização ou outras formas de armamentismo entre os pretendentes emergentes, fora da "zona de influência norte-americana", sobretudo os que se sentem ameaçados tanto pelos vizinhos poderosos e agressivos, como pelos próprios "grandes" que possuem armas nucleares ${ }^{19}$.

O que se esconde por trás do debate sobre o multipolarismo é uma enorme simplificação da ordem mundial existente. A Rússia precisa moderar suas aspirações a um pólo autônomo num mundo multipolar, que estaria alicerçado no seu papel central na Eurásia. Em primeiro lugar, ela será temida como uma potência hegemônica, tanto pelo Ocidente, como pelo Oriente. Em segundo lugar, ela deverá sacrificar sua aproximação com os dois ao mesmo tempo, se armando num pólo estratégico autônomo, voltando a glorificar o fantasma de uma superpotência. Em terceiro lugar, o sonho de prosperidade para seu povo poderá ser esquecido.

\section{O que mudou depois de 11 de setembro de 2001?}

Quais, então, as saídas dos impasses do círculo vicioso dos conceitos, dos vetores e dos ismos e as soluções a que a política externa russa deve chegar, fortalecendo suas posições no mundo contemporâneo? O Presidente Putin achou uma solução mágica ao propor uma mudança em caminho, surpreendendo quase todos os políticos nacionais e estrangeiros. Ao terem ocorrido os ataques terroristas de 11 de setembro nos Estados Unidos, a Rússia elaborou e executou uma série de medidas rápidas e eficazes na área de política externa que resultaram numa importante abertura com a Otan, com os Estados Unidos, com a União Européia e com vários parceiros asiáticos. Mas o progresso mais surpreendente, sem dúvida alguma, foi realizado nas relações com o bloco ocidental e, mais especificamente, com os Estados Unidos da América. 
Primeiro. Houve um desbloqueio das relações da Rússia com a Otan que já durava desde a crise em Kosovo em 1999. Em 28 de maio de 2002, na reunião da cúpula entre a Rússia e a Otan realizada na Itália, foi estabelecido o Conselho Otan-Rússia e foram instalados dois grupos de trabalho, um sobre a cooperação em tecnologias nucleares avançadas e outro em reduções de materiais nucleares cujos programas prevêem a eliminação de um volume de material nuclear sem precedente na história do desarmamento, equivalente à quantidade necessária para a fabricação de 25.000 ogivas nucleares.

Na Declaração dos Chefes de Estado e Governo dos Estados-Membros da Otan e da Federação Russa, foram reafirmados os objetivos, princípios e compromissos estabelecidos na Ata Fundamental das Relações entre a Rússia e a Otan de 1997, e em particular, a determinação de construir juntos uma paz duradoura e inclusiva na área euro-atlântica, com base na democracia e segurança cooperativa e no princípio de que a segurança de todos os Estados da comunidade euro-atlântica é indivisível. Uma nova era nas relações, anunciada na Declaração, implicar-se-á consultas e decisões conjuntas sobre a avaliação das ameaças comuns, gerenciamento de crises, não-proliferação das ADM, controle de armamentos e medidas de construção de confiança (com base no Acordo de Adaptação do Tratado das Forças Armadas Convencionais), busca e resgate no mar, cooperação militar, reforma militar, emergências civis, novas ameaças e desafios. ${ }^{20} \mathrm{~A}$ pauta do Conselho OtanRússia pode parecer periférica por não tocar na essência das decisões coletivas da Otan na área estratégica, mas dentro do contexto geral europeu e mundial, essa pauta é uma excelente oportunidade, por intermédio da qual a Rússia pode pressionar pela solução de problemas de segurança européia e internacional.

O Conselho não autorizou o direito de veto à Rússia sobre as decisões da Otan. Mas a questão do veto não foi reivindicada pela Rússia uma vez que ela não aspira transformar-se num país-membro da Otan. Em virtude de sua autonomia militar e com base na conjuntura estratégica mundial, a Rússia não pediu garantias da Otan em defesa coletiva. Isso significa que a Rússia continuou a usufruir do direito soberano de providenciar sua própria segurança pelos seus próprios meios e criar alianças com base em suas decisões autônomas, sem se amarrar ao sistema de segurança coletiva da Otan.

As principais conclusões que se pode tirar a partir dessa nova realidade demonstram uma invejável durabilidade das posições e conviç̧ões dos negociadores e da liderança política russa com relação à Otan. De acordo com Presidente Putin, a Rússia não parte do entendimento de que a expansão da Otan é provocada pela necessidade. ${ }^{21}$ Mas ao entrar num relacionamento especial com a Otan, mantendo a independência e a autonomia de sua política de segurança, a Rússia conseguiu diminuir, senão eliminar, as percepções de agressividade entre os membros do bloco ocidental. Por outro lado, as relações da Rússia com a Otan tornaram-se um meio da influência russa sobre a transformação presente e futura da aliança e sua inserção na arquitetura euroatlântica de segurança ${ }^{22}$. 
Tudo isso não significa que a Rússia gostaria de ser e a Otan gostaria de aceitá-la como país-membro. Os membros da organização, sobretudo os Estados Unidos, estariam contrários à adesão da Rússia à Otan por dois motivos: a) haveria na Otan um centro de decisão política de grande peso que poderia desestabilizar as relações transatlânticas, baseadas na desproporcionalidade do poderio militar dos Estados Unidos e da Europa; b) a adesão da Rússia conduziria os Estados Unidos até as fronteiras da China, o que poderia provocar uma reação chinesa desmesurada para proteger a sua segurança, criando uma percepção de ameaça americano-russa no âmbito da política externa da China.

Ao mesmo tempo, não seria escusado dizer que a decisão de aproximação da liderança russa com a aliança não encontrou críticas referentes ao aumento da fragilidade estratégica do país face à nova fase da expansão da Otan, decidida na cúpula de Praga do Conselho Atlântico ${ }^{23}$. No entanto, a atuação ágil da diplomacia russa permitiu ajustar o relacionamento estratégico com a Europa Ocidental e os Estados Unidos às novas realidades que surgiram depois de 11 de setembro.

Segundo. A Rússia modificou de uma maneira vigorosa, e sem se dar o luxo de hesitações, o relacionamento com os Estados Unidos, reconhecendo não somente de jure, mas também de facto, que os Estados Unidos não representam mais uma ameaça à Rússia. Dois principais fatos merecem ser mencionados a respeito.

Durante a Cúpula de 24 de maio de 2002 em Moscou, na Declaração Conjunta do Presidente George W. Bush e do Presidente Vladimir V. Putin sobre o Novo Relacionamento Estratégico entre os Estados Unidos da América e a Federação Russa, os dois lados declararam que a era em que os Estados Unidos e a Rússia tratavam um ao outro como inimigos ou como ameaça estratégica acabou. São parceiros e vão cooperar para promover a estabilidade, segurança, integração econômica e enfrentar juntos os desafios globais e ajudar a solucionar conflitos regionais. Respeitarão os valores essenciais de democracia, direitos humanos, liberdade de expressão e mídia livre, direito da lei e oportunidades econômicas. Tudo isso será a fundação para a cooperação entre eles. Ao rejeitar o modelo de rivalidade entre grandes potências, os dois presidentes fortaleceram seus compromissos referentes ao combate do terrorismo internacional. ${ }^{24}$

Na mesma ocasião foi celebrado o Tratado sobre as Reduções de Potenciais Estratégicos, conhecido como o Tratado de Moscou, que ultrapassou de longe os números das reduções, mencionados no Tratado Start II. Os limites das ogivas instaladas de cada lado foram estabelecidos no patamar de 1700 a 2200 e deveria ser atingido até o ano 2012. Essas reduções fixaram a meta de diminuição em dois terços da dimensão atual dos arsenais dos Estados Unidos e da Rússia, que, de acordo com as regras de contagem do Tratado Start I de 1991, consistem de 6000 e 5500 ogivas estratégicas nucleares respectivamente.

A reação a esse segundo fato, considerado um significativo sucesso pelos representantes oficiais por ter confirmado palpavelmente a solidez dos novos passos 
de aproximação estratégica, foi mista, de maneira que o Tratado provocou uma censura na Duma e entre especialistas em problemas estratégicos. Segundo eles, o Tratado deixa sem solução a implementação do cronograma de desinstalação das ogivas, as questões de quantas unidades serão destruídas e quantas guardadas, como elas serão armazenadas e protegidas e como será inspecionada a implementação do Tratado. A crítica partia da suspeita de que os Estados Unidos não se comprometeram a destruí-las, deixando dúvidas sobre a possibilidade de guardá-las para poder reinstalá-las poucos meses depois da expiração do Tratado em 2012. ${ }^{25}$

Desde que o Tratado não obrigou as partes a destruir as ogivas carregadas, ele deixou a Rússia numa posição desvantajosa, forçando-a a reduzir o seu arsenal nuclear instalado por razões econômicas, por não poder sustentar a manutenção das ogivas nucleares em regime operacional. Isso significa que em caso de uma mudança na situação estratégica e na percepção de ameaça, os Estados Unidos seriam capazes de reconstituir seu arsenal nuclear rapidamente. ${ }^{26}$

Ao mesmo tempo, a posição oficial foi coerente e firme. $\mathrm{O}$ tratado, segundo seus defensores, é o último documento de desarmamento da época de confronto e o primeiro da era de cooperação e de confiança. O termo "potenciais" altera a abordagem do problema do desarmamento, reunindo ogivas, portadores, vinculando os sistemas ofensivo e de defesa estratégica, em referência feita à Declaração conjunta do Presidente da Rússia e do Presidente dos Estados Unidos em Gênova em 22 de junho de $2001^{27}$, assim permitindo uma liberdade de ação na composição das forças nucleares de cada lado.

O argumento mais consistente que fortifica a posição de Putin insere-se na lógica integral e complexa do processo de desarmamento, da evolução das armas de destruição em massa e do sistema de defesa antimíssil. De acordo com o ministro de defesa da Rússia Serguei Ivanov, o novo Tratado estabelece a vinculação entre os armamentos ofensivos e defensivos. A Rússia está possibilitada de conservar as Mirvs (ogivas múltiplas) existentes e futuras porque o Tratado Start II não entrou em vigor. Isso é um importante fator de dissuasão, sobretudo nas condições dos testes e da criação dos sistemas antibalísticos norte-americanos. A transparência e medidas de confiança em relação à NMD foram a forma por meio da qual a Rússia estabeleceu a cooperação com os Estados Unidos no âmbito da defesa anti-mísseis, por via de trocas de experiências e de informações e por meio de exercícios e pesquisas conjuntas, em nível bilateral e multilateral, inclusive na Europa, por intermédio da estrutura do Conselho Otan-Rússia ${ }^{28}$. O referido progresso ajudou a ultrapassar o impasse criado pela retirada unilateral dos Estados Unidos do Tratado ABM.

Essa evolução das relações russo-americanas representou uma nova qualidade da parceria entre os dois ex-rivais que pôs termo à psicologia bipolar da Guerra Fria nas relações bilaterias. O Tratado sobre as Reduções de Potenciais 
Estratégicos eliminou o conceito da paridade estratégico-militar entre os Estados Unidos e a Rússia, pedra fundamental do maior confronto da Guerra Fria. Como afirmou Putin, "Depois de 11 de setembro, muitos, bem muitos no mundo compreenderam que a Guerra Fria acabou. Compreenderam que agora a ameaças são outras e uma outra guerra está sendo travada, a guerra contra o terrorismo internacional." 29

Terceiro. Devemos assinalar a cooperação anti e contraterrorista entre a Rússia e os Estados Unidos que se estabeleceu depois de 11 de setembro. Putin propulsionou a Rússia para ser um dos mais importantes aliados dos Estados Unidos na guerra internacional contra o terrorismo. O sinal verde dado pela Rússia para o desembarque das tropas norte-americanas no Tadjiquistão e no Uzbequistão aumentou significativamente a capacidade dos Estados Unidos de conduzir as operações militares no Afeganistão contra o regime talibã e na região asiática em geral. Graças a essa cooperação, a Rússia conseguiu obter a qualificação pelos Estados Unidos de vários grupos separatistas chechenos como grupos terroristas internacionais, ao ter provado a existência de vínculos entre os combatentes da república rebelde de Itchquéria ${ }^{30}$, uma ditadura obscurantista baseada nas leis do shariá, e Al-Qaeda, a realização de transferências financeiras pelas organizações terroristas internacionais e a contratação dos mercenários estrangeiros islâmicos para a guerra contra a Rússia. A inclusão e o papel ativo da Rússia na guerra contra o terrorismo internacional, que coincide com os objetivos estratégicos da Rússia no combate à ameaça do fundamentalismo islâmico para sua segurança interna e integridade territorial, definiram a importância-chave da Rússia na coalizão internacional contra o terrorismo.

Quarto. A Rússia conseguiu o reconhecimento por parte dos Estados Unidos e da UE da economia russa como economia de mercado, abrindo o caminho para a entrada na OMC. A admissão da Rússia como membro de plenos direitos do G-8 a partir de 2006 e seu ingresso na OCDE nos meados da década corrente são frutos de sua recuperação econômica e de sua modernização, que serão seguidos pela estabilização econômica do país e pela ascensão à posição de liderança regional, contribuindo para o status de respeitabilidade e de peso político no sistema internacional.

A visão de Putin pode ser comparada com a de Deng Xiaoping que há mais de 20 anos concluiu que a recuperação da China a longo prazo seria fundamental para a recuperação da sua influência internacional e para a prosperidade do povo chinês ${ }^{31}$.

Quinto. O Grupo de Xangai, ou Organização de Cooperação de Xangai, que foi criado em 1996 entre cinco países fronteiriços da China (Rússia, China, Casaquistão, Quirguízia e Tadjiquistão) para aparar as arestas referentes à delimitação das fronteiras comuns com a China, depois de 11 de setembro, definiuse como um organismo regional de cooperação em uma vasta gama de assuntos, 
dos quais a luta antiterrorista se tornou prioritária. Além disso, a cooperação política e econômica do Grupo ficaram atraentes a vários países da região como Paquistão e Uzbequistão, que integraram-se ao Grupo. No momento atual esse grupo representa um núcleo de integração regional crescente que gradualmente preenche o vácuo de cooperação criado depois da dissolução da União Soviética na região da Ásia Central.

Sexto. A participação do Fórum do APEC desde 1998 insere-se no contexto da "missão eurasiática" da Rússia, realizada no âmbito da evolução do mercado global. O atraso na inclusão das vastas regiões siberianas na economia mundial e, sobretudo, na zona de crescimento econômico mundial mais dinâmico, que é o APEC, impele os dirigentes russos a fazer esforços significativos na abertura corajosa nessa direção. De acordo com as teses do Presidente Vladimir Putin expostas na cúpula do Fórum em outubro de 2001, as direções prioritárias da política externa russa serão: a diversificação de comércio com os países-membros do Fórum, transferindo a ênfase dos parceiros tradicionais para parceiros novos na região; a criação de uma nova configuração energética na região da Ásia e Pacífico a fim de valorizar os interesses da Rússia; a proposta de a Rússia servir de "ponte" entre a Ásia e Pacífico e a Europa, baseada na infra-estrutura de transportes; o caminho de inovações tecnológicas e científicas, apoiadas pelo capital humano intelectual científico russo ${ }^{32}$.

Como podemos resumir as mudanças que têm ocorrido e estão ocorrendo na política externa russa? A conclusão à qual estou chegando é que o que ocorreu foi uma reavaliação da base doutrinária da política externa russa depois de 11 de setembro, que podemos resumir de maneira seguinte.

1. Houve uma clara evolução, partindo da rigidez e da ilusão do status de grande potência em direção a uma flexibilidade em assuntos internacionais, diminuindo uma dependência excessiva dos dogmas conceituais, como a multipolaridade, por exemplo. Sem abandonar o conceito multipolar, a Rússia amenizou e abrandou as fórmulas de sua aplicação. É sintomático o que escreve Alexei Meshkov, vice-Ministro de Negócios Estrangeiros da Rússia na véspera da cúpula Bush-Putin em maio de 2002: “Nós, na Rússia, fizemos uma opção clara a favor do mundo multipolar [...] Pronunciamo-nos pela formulação de atitudes multilaterais ao problema de garantias de segurança internacional, pelas ações comuns frente às novas ameaças e riscos [...] A nossa visão do mundo multipolar pressupõe antes de mais nada uma cooperação entre centros de poder e não a rivalidade como já aconteceu no passado" ${ }^{33}$. Se se levar em consideração que o papel central das Nações Unidas na formulação da ordem mundial também foi destacado, então, é evidente que uma mudança a favor de um flexível contexto de alianças, de um multilateralismo baseado na cooperação com os atuais centros de poder, sem a visível preocupação com a construção de seu status global, mas com o papel central da ONU. 
2. O que impressiona é o pragmatismo de Putin, que, ao que parece, tem que vencer uma resistência considerável dentro dos altos escalões de poder para tomar as decisões arrojadas e inovadoras. Essa atitude pragmática indica um incremento de flexibilidade e uma adaptabilidade surpreendente às exigências da etapa atual de relações internacionais. Mesmo podendo parecer táticas, as alterações tocam na estrutura das relações construídas durante décadas, transformando, desse modo, o pragmatismo num instrumento prático de uma rápida e eficiente inserção internacional.

3. A opção estratégica discutida acima parece mais nítida do que antes. A Rússia sai do patamar da discussão de exclusividade de tal ou tal orientação na política externa, preferindo que as necessidades do momento definam sua opção atual. Ela posiciona-se no patamar de aproveitamento de oportunidades que surgem e podem surgir em todas as direções da política externa, preferindo uma opção multivetorial. Citando Alexei Meshkov: "No decorrer da história da Rússia desenrolava-se uma discussão profunda sobre qual devia ser o seu vetor principal - oriental ou ocidental. Agora essa opção é feita, isto é: ambos os vetores - tanto asiático, quanto euro-atlântico - têm seu valor individual do ponto de vista dos interesses nacionais, segundo uma dinamização da política externa em todos os azimutes" ${ }^{34}$ (sublinhado pelo autor por causa da alusão de Alexei Meshkov à política externa de De Gaulle nos anos 60 - à tous les azimuts).

O caráter multivetorial, a ação pragmática e a cooperação multilateral na política externa russa, além de adaptar o relacionamento da Rússia com os Estados Unidos, a aproximam de outros grandes atores no âmbito das novas realidades internacionais, como o Brasil, o México, a Austrália, o Canadá e a Indonésia, lançando bases para uma diversificação e uma integração de seus esforços de desenvolvimento e de modernização em diversas regiões e continentes, com grandes e médios parceiros econômicos e comerciais em variados assuntos da agenda global e regional.

\section{Conclusão}

A realidade e a verdade são sempre mais complicadas do que podemos imaginar e elas provocam questionamentos. O mais importante deles é: essa mudança brusca no caminho, resultante dos acontecimentos de 11 de setembro é uma estratégia elaborada, cuidadosamente preparada, ou é uma expediência política ou uma espécie de oportunismo? É um caminho em direção à ocidentalização ou é um estratagema a curto prazo de cálculo de custos-benefícios? Usando outros termos, é um quid pro quo tático, uma consequência da incapacidade econômica de permitir um novo ciclo de rivalidade pelo poder mundial, ou um Grand Dessein idealista do Presidente Putin?

A explicação quid pro quo tem suficientes razões para ser mencionada. Mesmo sem aproveitamento absoluto, Moscou conseguiu obter benefícios reais 
resultantes de sua nova postura pós-11 de setembro: suas relações com os Estados Unidos e a Otan melhoraram bastante sobre toda a agenda de segurança internacional e euro-atlântica, seu processo de entrada na OMC recebeu incentivos da parte dos líderes ocidentais de comércio internacional, suas tentativas de obter um abrandamento da crítica de direitos humanos na Chechênia foram bemsucedidas. Portanto, os benefícios internos e externos, mesmo relativos, foram satisfatórios. Ao mesmo tempo, a Rússia não conseguiu evitar a segunda rodada da expansão da Otan e a retirada dos Estados Unidos do Tratado ABM.

A desmilitarização e a modernização do exército russo, que diminuiu de 1,9 milhões para 900. 000 em menos de uma década, aliviando a Rússia de um peso de gastos improdutivos, demonstram não somente a restrição econômica à entrada num novo ciclo de rivalidade pelo poder mundial, como também a compatibilização dos objetivos políticos internos e externos da Rússia com as novas tendências mundiais, como a globalização econômica, financeira e comercial, a integração regional, a diminuição da ameaça de um conflito global e o surgimento de novos padrões de segurança nacional e internacional.

Não acredito num Grand Dessein do Presidente Putin. Ele ainda não acumulou uma experiência política suficiente para poder lançar um "tratado de paz perpétua” e de reestruturação da ordem mundial. Assim como a própria Rússia não se encontra em condições de ser uma proponente de idéias de vulto e de grandeza na cena mundial sem ser suspeita de hegemonismo, embora as discussões em torno de uma "via russa" se identifiquem com cenários democratizantes da evolução mundial.

Ao mesmo tempo, gostaria de tocar nas mudanças na política dos Estados Unidos, que provocam, de maneira objetiva e convincente, a metamorfose na política externa russa. A constatação nos Estados Unidos de um agravamento durante os últimos anos das relações com a Rússia e a China revelou uma perspectiva desagradável de que os dois países poderão potencialmente se transformar em maiores rivais do poder norte-americano. Face à previsão de que os derrotados da Guerra Fria poderiam se sentir “traídos” pelo Estados Unidos e, portanto, criar sentimentos antiamericanos, evoluindo posteriormente numa situação de “conflitos inadvertentes”, uma mudança de estratégia, no sentido de reaproximação com os dois gigantes, foi insistentemente recomendada ${ }^{35}$. $\mathrm{Na}$ Estratégia de Segurança Nacional dos Estados Unidos da América, o Presidente George W. Bush refere-se especificamente aos dois países no preâmbulo do documento com a mensagem de que "a América irá incentivar o avanço de democracia e da abertura econômica em ambas as nações, pois essas são as melhores bases para a estabilidade interna e para a ordem internacional”36. Com relação à Rússia, essa proposta estratégica está baseada na mudança de pensamento ocorrida na Rússia, no sentido de que os dois países não são mais adversários estratégicos, que a Rússia tem avaliação realista de suas fragilidades 
e entende que as atitudes da Guerra Fria não servem mais seus interesses nacionais ${ }^{37}$. Por existir "a preocupação com a potencial transformação da Rússia em grande potência, exercendo um papel que pode ultrapassar a sua condição de líder regional”38, o compromisso com a integração da Rússia numa comunidade euroatlântica, que se estenderia ao entorno pós-soviético, é colocado como um objetivo prioritário dos Estados Unidos da América. Essa reviravolta na atitude norteamericana em relação à Rússia cria condições para a parceria duradoura nas relações da Rússia com os Estados Unidos e com os países ocidentais em geral.

É importante saber qual a perspectiva que a Rússia traça para seu futuro político interno e externo. A política russa no contexto atual baseia-se na previsibilidade e estabilidade de suas doutrinas, políticas e preferências realizadas mediante o esquema de "engajamento pragmático", com base na ampliação de cooperação multivetorial e multilateral, contando com benefícios mistos. A participação eficaz da cooperação no âmbito da agenda global a aproxima do Ocidente e do Oriente, dos países ricos e pobres, dos blocos regionais e dos organismos transnacionais. A concentração na melhoria das posições da Rússia no "exterior próximo" realça a seriedade da intenção da Rússia de se manter como líder regional do espaço pós-soviético.

No entanto, é importante sublinhar que as fragilidades da Rússia acima mencionadas originam-se da transição que está ocorrendo no seu sistema político em direção à democracia, na sua economia em direção ao mercado, na sua sociedade em direção ao Estado de direito e à sociedade civil evoluída. Enquanto a Rússia não criou um sistema eficaz e seguro de gestão democrática interna e de responsabilidades externas, baseadas em valores compartilhados, a pior estabilidade é melhor do que um excelente caos. Por essa razão, a posição da Rússia no cenário mundial depende da manutenção de estabilidade econômica, política, federal e da continuidade de suas reformas internas.

As críticas a esse respeito tocam na reforma do Estado que é considerada cosmética, o papel reformador de Putin sendo assim posto em dúvida. O Presidente, dizem críticos e oponentes, daqui a pouco será dissuadido de andar tão rápido em direção à aliança com a "hegemonia unipolar" que é capaz de minar as posições da Rússia no “anel de boa-vizinhança”, sobretudo na Ásia Central. Ele conseguiu debilitar, mas não derrubou os oligarcas. Está tímido na reforma econômica e não respeita os direitos da mídia. A Rússia precisa de reforma, de governança boa e responsável, de transparência e de controlabilidade. Caso essas mudanças não ocorram, nada acontecerá, e os grandes planos anunciados nas cimeiras russoeuropéias, russo-americanas ou russo-asiáticas serão fracassados. ${ }^{39}$ Nesse caso, "o novo autoritarismo pode ser um problema maior para a integração russa com o Ocidente do que o novo imperialismo russo." 40

Uma resposta provável a essa crítica é que, se a Rússia mudar sua política doméstica, e se o Ocidente se alinhar aos interesses nacionais da Rússia, então, 
poder-se-á dizer que a estratégia pós-11 de setembro da parte da Rússia é uma decisão de longo prazo. Esse parece o cenário mais plausível. A Rússia fez a sua opção no mundo contemporâneo e, em conseqüência das transformações de fundo, a integração do país na sociedade democrática internacional é irreversível. O país é uma jovem democracia e sua política externa é previsível e estável. Em torno da política externa russa existe um consenso da sociedade. O interesse nacional russo é formulado de maneira precisa:

- a criação das condições favoráveis para o desenvolvimento econômico do País: segurança, ordem constitucional, consolidação da sociedade civil e incentivos ao empresariado;

- a continuidade histórica: paz externa para o bem da evolução interna;

- a construção, junto com a sociedade internacional, da ordem democrática mundial.

O passo mais importante na direção de uma nova postura internacional foi dado. A Rússia, ao optar pela pragmaticidade, pelo caráter multi-eixo de sua política externa e pelo ocidentalismo de cunho europeísta, lançou bases para suas respeitabilidade e autonomia nas estruturas políticas internacionais, sua responsabilidade internacional, sintonizada com os objetivos da sociedade internacional consagrados na Carta das Nações Unidas, nos documentos do direito internacional e baseada na comunidade de interesses na construção de uma segurança euro-atlântica e euro-asiática, do mercado único, de um mundo mais justo e mais pacífico.

Maio de 2003

\section{Notas}

1 NAROCHNITSKAYA, Natalyia. The Russian Challenge - A sensation in politology. The book of Viktor Lupan. International Affairs, Moscou, 2001. N. 5, p. 87-96; GROGORASH, Alexander Vorontsov. The first Russian Empire minister of foreign affairs. International Affairs Moscou, 2001. N. 6, p. 85-97; YEMETS, Valentin. Russian Empire Ministry of Foreign Affairs. International Affairs Moscou, 2001. N. 6, p. 98-112; ANISIMOV, Evgeny. When the last "diplomatic convoy" has gone. International Affairs, Moscou, 2000. N. 1, p. 76-86.

2 Câmara de deputados do parlamento da Rússia.

3 PUSHKOV, Alexei. Russia in the new world order: side by side with the West or by itself? International Affairs, Moscou, 2000. N. 10, p. 33.

4 Uma proposta de parceria estratégica, anunciada em 1998 pelo então primeiro-ministro da Rússia Evgueni Primakov. (Ver PRIMAKOV, Evgueni. Gody v bolshoi politikje. Moskva: Sovershenno sekretno, 1999, p.198).

5 KOZYREV, Andrei. Risks: our own and those of the others. Moscow News, August, 2000. N. 30 (1048).

6 GLOBALNOYIE, Soobschestvo. Novayia sistema koordinat. Sankt-Peterburg: Aleteia, 2000; Panarin, A.S. GLOBALNOYIE politicheskoyie prognozirovaniyie. Moskva: Algoritm, 2000. 
7 "It is time to stop pretending that Europeans and Americans share a common view of the world, or even that they occupy the same world. On the all-important question of power the efficacy of power, the morality of power, the desirability of power - American and European perspectives are diverging. Europe is turning away from power, or to put it a little differently, it is moving beyond power into a self-contained world of laws and rules and transnational negotiation and cooperation. It is entering a post-historical paradise of peace and relative prosperity, the realization of Kant's "Perpetual Peace." The United States, meanwhile, remains mired in history, exercising power in the anarchic Hobbesian world where international laws and rules are unreliable and where true security and the defense and promotion of a liberal order still depend on the possession and use of military might... The reasons for the transatlantic divide are deep, long in development, and likely to endure. When it comes to setting national priorities, determining threats, defining challenges, and fashioning and implementing foreign and defense policies, the United States and Europe have parted ways.” (In: KAGAN, Robert. Power and Weakness. Policy Review, jun/jul, 2002. N. 113. Disponível em: <http://www.policyreview.org/>. Acessado em: 08 janeiro 2003. JAGUARIBE, Hélio. O que é o “Ocidente”? Política Externa, mar/abr/maio, 2002.V. 10, n. 4, p. $110-111$.

9 O reconhecimento pela parte do Ocidente de que a Rússia é uma economia de mercado foi feito em julho de 2002 pelos Estados Unidos da América e pela União Européia, desimpedindo o caminho para a adesão da Rússia à OMC.

10 IVANOV, Igor S. “Novosti”. 27 dez. 2002. Disponível em : <http://www.ln.mid.ru>. Acessado em: 02 janeiro 2003. Entrevista concedida à Agência RIA.

11 MANILOV, Valery. On the military doctrine of Russia. International Affairs, Moscou, 2000. N. 5, p. 44.

12 Pelo Acordo de Adaptação do Tratado de Limitação das Forças Armadas Convencionais na Europa, assinado em 1999 em Istanbul, a Rússia conseguiu diminuir limitações, referentes aos flancos, impostas pelo Tratado em 1990, quando ainda existia o Pacto de Varsóvia, bem como minimizar as consequências militares da expansão da Otan, enfatizando a responsabilidade individual dos países europeus, repartidos em dezenove zonas de níveis de armamentos, de não permitir a transferência de forças armadas e de armamentos convencionais de uma zona para outra (Ver. CHERNOV, Vladislav. Arms limitation treaty in Europe and security of Russia. International Affairs, Moscou, 2002. N. 5, p. 26-32).

13 A Comunidade Econômica da Eurásia, estabelecida em 23 de maio de 2000, integra Belarus, Casaquistão, Rússia, Quirguistão e Tadjiquistão, com o objetivo de implantar a União Aduaneira e o Espaço Econômico Único entre os cinco países-membros. Disponível em: <http:// mpa.rbc.ru/ru/establishment/docs/>. Acessado em: 08 fevereiro 2003.

14 TRIANGULAR DIPLOMACY. The New York Times, 20 julho 2001.

15 MENSAGEM DO PRESIDENTE DA FEDERAÇÃO RUSSA VLADIMIR PUTIN PARA A ASSEMBLÉIA FEDERAL DA FEDERAÇÃO RUSSA. International Affairs, Moscou, 2001. N. 5, p. 97-111.

16 Foreign Policy Concept of the Russian Federation. International Affairs, Moscou, 2000. N. 8-9, p.3-14.

17 BRZEZINSKI, Zbigniew. Living with Russia. The National Interest, Fall, 2000. N. 61, p. 11-12.

18 Trata-se da preparação do referendo, em que será discutida a constituição da Chechênia.

19 BALUYEVSKY, Yury. Russian-American relations. The new model. International Affairs, Moscou, 2002. N. 8, p. 48.

20 STAUDENMEYER, Ingrid Scoville Herbert J. Summary and Accomplishments of the BushPutin Presidential Summit, maio, 2002. Disponível em: <http://www.armscontrol.org>. Acessado em: 26 novembro 2002. 
21 CONFERÊNCIA DE IMPRENSA DO PRESIDENTE V.V. PUTIN E DO PRESIDENTE G.W. BUSH DEPOIS DAS NEGOCIAÇÕES RUSSO-AMERICANAS. Pushkin, 22 nov. 2002. Disponível em: <http://www.ln.mid.ru/ns-osndoc.nsf/>. Acessado em: 02 janeiro 2003.

22 GRUSHKO, Alexander. Russia - NATO. G20 seems to start rolling. International Affairs, Moscou, 2002. N. 7, p. 89-90.

23 SKOLKO NATO? Rossiiskaya Gazeta, 16 nov. 2002. N. 218 (3086). Disponível em: <http:/ www.rg.ru>. Acessado em: 16 novembro 2002.; The NATO thanks Russia for the Baltics. Rossiiskaya Gazeta, 09 dez. 2002. Disponível em: <http:/ www.gazeta.ru>. Acessado em: 09 dezembro 2002.

24 STAUDENMEYER, Ingrid Scoville Herbert J. Op. cit. Disponível em: <http:// www.armscontrol.org>. Acessado em: 26 novembro 2002.

25 KORTUNOV, Sergei. Washinton is renouncing the ABM Treaty. International Affairs, Moscou, 2002. N. 7, p. 68-74.

26 KUCHINS, Andrew. Explaining Mr. Putin: Russia’s new nuclear diplomacy. Arms Control Today, out, 2002. Disponível em: <http://www.armscontrol.org/act/2002_10/kuchinsoct02.asp?>. Acessado em: 26 novembro 2002.

27 BALUYEVSKY, Yury. Op. cit. p. 55-56.

28 IVANOV, Sergei. Strategical stability at the present stage. International Affairs, Moscou, 2002. N. 8, p. 17-20.

29 MENSAGEM DO PRESIDENTE DA FEDERAÇÃO RUSSA VLADIMIR PUTIN PARA A ASSEMBLÉIA FEDERAL DA FEDERAÇÃO RUSSA. International Affairs, Moscou, 2002. N. 5, p. 17.

30 Denominação da Chechênia em documentos oficias do governo separatista.

31 KUCHINS, Andrew. Op. cit. Disponível em: <http://www.armscontrol.org/act/2002_10/ kuchinsoct02.asp?>. Acessado em: 26 novembro 2002.

32 LOSYUKOV, Alexander. Russia and Shangai summit. International Affairs, Moscou, 2001. N. 11, p.25-26.

33 MESHKOV, Alexei. Actual aspects of Russian foreign policy. International Affairs, Moscou, 2002. N. 4, p.56

34 Idem, p.57

35 MCNAMARA, Robert S. \& BLIGHT, G. In from the cold: a new approach to relations with Russia and China. World Policy Journal, Spring, 2001, p. 67-77.

36 BUSH, George W. A estratégia de Segurança Nacional dos Estados Unidos da América. Política Externa, dez/jan/fev, 2002/2003. V. 11, n. 3, p. 80.

37 BUSH, George W. Idem, p. 106-107.

38 POMERANZ, Lenina. A nova estratégia e a Rússia. Política Externa, dez/jan/fev 2002/ 2003. V. 11, n. 3, p. 71.

39 YAVLINSKY, Grigori. BBC, 20 nov. 2001. Entrevista concedida a Tim Sebastian.

40 SESTANOVICH, Stephen. Where does Russia belong? The National Interest, Winter 2000/ 2001. N. 62, p.5-16.

\section{Referências bibliográficas:}

BALUYEVSKY, Yury. Russian-American relations: the new model. International Affairs, Moscou, 2002. N. 8, p. 48.

BRZEZINSKI, Zbigniew. Living with Russia. The National Interest, 2000. N. o 61, Fall, p. 5-16. BUSH, George W. A estratégia de Segurança Nacional dos Estados Unidos da América.

Política Externa, dez/jan/fev, 2002/2003. V. 11, n. 3, p. 80. 
DELYAGIN, Mikhail. Has Russia a strength to meet “a new pragmatism” of the USA? International Affairs, Moscou, 2001. N. ㅇ 3, p. 10-20.

FOREIGN Policy Concept of the Russian Federation.International Affairs, Moscow, 2000. N. 8/9, p. 3-14.

IVANOV, Igor. Russia in the world politics.International Affairs, Moscou, 2001. N. 5, p. 3-9.

IVANOV, Igor S. The New Russian Diplomacy. Washington D.C.: The Nixon Center \& Brookings Institution Press, 2002.

JAGUARIBE, Hélio. O que é o “Ocidente”? Política Externa, mar/abr/maio, 2002. V. 10, n.4, p. $110-111$.

KAGAN, Robert. Power and Weakness. Policy Review, n. 113, jun/jul, 2002. Disponível em: <http://www.policyreview.org/>. Acesso em: 08 janeiro 2003.

KOLTUNOV, Victor. The Challenges of the US NMD. International Affairs, Moscou, 2001. N. ${ }^{\circ}$ 4, p. 97-105.

KORTUNOV, Sergei. Washington is renouncing the ABM Treaty. International Affairs, Moscou, 2002. N. 7, p. 68-74.

KRIVOKHIZHA, Vasily. On the threshould of changes in the world order. International Affairs, Moscou, 2001. N. 4, p. 30-39.

KUCHINS, Andrew. Explaining Mr. Putin: Russia’s new nuclear diplomacy. Arms Control Today, out, 2002. Disponível em: <http://www.armscontrol.org/act/2002_10/ kuchinsoct02.asp?> . Acessado em: 26 novembro 2002.

LIEVEN, Anatol. Against Russophobia. World Policy Journal, Winter, 2000/2001.V. XVII, n. 4, p.25-32.

LOSYUKOV, Alexander. Russia and Shangai summit. International Affairs, Moscou, 2001. N. 11, p.25-26.

MANILOV, Valery. On the military doctrine of Russia. International Affairs, Moscou, 2000. N. 5, p. 44.

McNAMARA, Robert S. \& BLIGHT, G. James. In from the cold. A new approach to relations with Russia and China. World Policy Journal, Spring, 2001, p. 67-77.

MESHKOV, Alexei. Actual aspects of Russian foreign policy. International Affairs, Moscou, 2002. N. 4, p.56

MESSAGE OF THE PRESIDENT OF THE RUSSIAN FEDERATION VLADIMIR PUTIN TO THE FEDERAL ASSEMBLY OF THE RUSSIAN FEDERATION. International Affairs, Moscou, 2001. N. 5, p. 97-111.

MESSAGE OF THE PRESIDENT OF THE RUSSIAN FEDERATION VLADIMIR PUTIN TO THE FEDERAL ASSEMBLY OF THE RUSSIAN FEDERATION. International Affairs, Moscou, 2002. N. 5, p. 3-18.

POMERANZ, Lenina. A nova estratégia e a Rússia. Política Externa, dez/jan/fev, 2002/ 2003. V. 11, n. 3, p. 71.

PUSHKOV, Alexei. Russia in the new world order: side by side with the West or by itself? International Affairs, Moscou, 2000. N. 10, p. 33-44.

CADERNOS ADENAUER 5. A Rússia no início da era Putin. São Paulo: Fundação Konrad Adenauer, jul, 2000.

U.S.-RUSSIAN RELATIONS IN THE POST-SEPTEMBER 11 WORLD. Congressional strategic stability and security seminar series, 19 abr. 2002. Disponível em: <http://www.armscontrol.org>. Acessado em: 26 novembro 2002. 
THE RUSSIAN FEDERATION. CONCEPT OF THE WORLD IN THE $21^{\text {ST }}$ CENTURY. Permanent mission of the Russia Federation to the United Nations. Disponível em: $<$ http://www.un.int/russia/>. Acessado em: 08 janeiro 2003.

SESTANOVICH, Stephen. Where does Russia belong? The National Interest, Winter, 2000/2001. N. 62, p. 5-16.

STAUDENMEYER, Ingrid Scoville Herbert J. Summary and Accomplishments of the BushPutin Presidential Summit, maio, 2002. Disponível em: <http://www.armscontrol.org>. Acessado em: 26 novembro 2002.

TRENIN, Dmitri. The End of Eurasia: Russia on the border between geopolitics and globalization. Washington D.C.: Carnegie Endowment for International Peace, 2002. TRIANGULAR DIPLOMACY. The New York Times, 20 jul 2001.

YAVLINSKY, Grigori. BBC, 20 nov. 2001. Entrevista concedida a Tim Sebastian.

\section{Resumo}

O artigo persegue o objetivo de definir o lugar e o papel da Rússia nas relações internacionais contemporâneas nos últimos anos. Ao se debruçar sobre o dilema tradicional da política externa russa - Ocidentalismo versus Orientalismo - o autor analisa o cenário de multipolaridade defendido pela nova concepção da política externa russa e o relaciona com a fase do pragmatismo e do multilateralismo que caracteriza a atuação internacional da Rússia de Putin, fazendo considerações, decorrentes do impacto dos ataques terroristas aos Estados Unidos em 11 de setembro de 2001 sobre a política externa russa. A atitude pragmática e a natureza multivetorial da política externa russa contribuem, segundo o autor, para o fortalecimento das posições internacionais da Rússia em comparação com a perda ou a natureza incerta das alianças e dos relacionamentos do período da transição pós-soviética.

\section{Abstract}

The article pursues the purpose to place Russia and its politics within the context of today's international relations. While discussing the traditional dilemma of the Russian foreign politics - Occidentalism versus Orientalism - the author analyses the scenario of multipolarity, backed up by the new Russian foreign policy concept. Hence it is related to the pragmatism and the multilateralism of the international posture of Putin's Russia, the author makes several considerations, which follow from the impact of the September $11^{\text {th }}$, 2001, terrorist attacks on the United States of America with regard to Russia's foreign policy. The pragmatic attitude and the multi-axis nature of the Russian foreign policy nowadays contribute, 
according to the author, to strengthen Russia's international background in comparison with the loss or the uncertain nature of alliances and relationships of the post-Soviet transition period.

Palavras-chave: Rússia; Política Externa; Ocidentalismo; Orientalismo; Mundo Multipolar; 11 de setembro de 2001.

Key words: Russia; Foreign Policy; Occidentalism; Orientalism; Multi-polar World; September 11 ${ }^{\text {th }}, 2001$. 